\title{
Effectiveness of an Improvement Writing Program According to Students' Reflexivity Levels
}

\author{
Jesús Nicasio García and Ana $\mathrm{M}^{\mathrm{a}}$ de Caso-Fuertes \\ Universidad de León
}

\begin{abstract}
After designing a writing program to enhance students' reflexivity and thus improve their compositions (García \& de Caso, 2002a, 2002b), the aim of the research project was to show how reflexivity levels could influence the effectiveness of this program. This writing instruction through reflexivity was carried out with 5 th and 6th grade students with learning disabilities (LD) and/or low achievement (LA) during 25 sessions. One hundred participants were assigned to either the experimental group $(n=49)$, which received specific intervention in writing and reflexivity, or the control group $(n=51)$, which simply received the ordinary curriculum. Both groups were assessed on the productivity and quality of their writing composition as well as their attitudes, self-efficacy, and reflexivity towards writing. The results show that coherence and reflexivity improved depending on the level of reflexivity, whereas the relationship with attitudes and self-efficacy is not so clear. Thus, it seems possible to improve LD and/or LA students' compositions by taking their reflexive style into account. Depending on the students' learning style, teachers should use either one or another technique.

Keywords: reflexivity towards writing, learning-disabled students, process planning, text planning, writing instruction
\end{abstract}

Tras el diseño de un programa de escritura para incrementar la reflexividad del alumno hacia la misma y mejorar así sus composiciones escritas (García \& de Caso, 2002a, 2002b), este estudio pretende mostrar cómo los niveles de reflexividad del alumno pueden influir en la eficacia de este programa. La instrucción en reflexividad hacia la escritura se llevó a cabo con alumnos con dificultades de aprendizaje y/o bajo rendimiento, de $5^{\circ}$ y $6^{\circ}$ de primaria, durante 25 sesiones. Los 100 participantes fueron asignados bien al grupo experimental $(n=49)$, que recibió el entrenamiento específico, bien al grupo control $(n=51)$, que sólo recibió currículum ordinario. Ambos grupos fueron evaluados tanto en productividad y calidad de las composiciones escritas como en actitudes, autoeficacia y reflexividad hacia la escritura. Los resultados muestran que no sólo la coherencia de los textos escritos sino también la reflexividad mejora dependiendo del nivel de reflexividad del alumno, mientras que la relación con actitudes y autoeficacia no está tan clara. De este modo, parece posible mejorar las composiciones escritas de los alumnos con dificultades de aprendizaje y/o bajo rendimiento teniendo en cuenta el estilo cognitivo de los mismos en nuestras intervenciones. Dependiendo de este estilo cognitivo, los profesores deben usar una u otra técnica.

Palabras clave: reflexividad hacia la escritura, estudiantes con dificultades de aprendizaje, planificación de procesos, planificación de textos, instrucción en escritura

During this research project, funds from Dirección General de Investigación del Ministerio de Educación y Ciencia de España [General Research Board of the Spanish Ministry of Education and Science], were awarded to the principal researcher (J.N. García).

We are very grateful to Jenny Gunn for the English correction.

Correspondence concerning this article should be addressed to Jesús Nicasio García Sánchez, Departamento de Psicología, Sociología y Filosofía, Psicología Evolutiva y de la Educación, Universidad de León, Campus de Vegazana, s/n, 44071 - León (Spain). E-mail: jn.garcia@unileon.es 
The study of the processes involved in writing has increased enormously over the last decade; there have been numerous investigations which have attempted to identify all the components implicated in the writing process (Alamargot \& Chanquoy, 2001). As a result of these studies, it has been discovered that composition writing involves not only cognitive and behavioral processes but also emotional and personality processes (Hayes, 1996; Kellogg, 1994). One of the personal elements which seems to have an influence on writing is the cognitive style, defined as an individual's preferred and habitual approach to organizing and representing information (Riding \& Rayner, 1998), and a component of this is the student's reflexivity-impulsivity level, because this could be understood as the tendency to reflect on alternative-solution possibilities, in contrast to the tendency to select a solution impulsively, in problems with high response uncertainty (Kagan, 1965a; Riding \& AlSanabani, 1998). Writing could be defined in terms of problem resolutions processes (Flower \& Hayes, 1981), and considered as one of the most complex tasks that a student must accomplish (Bruning \& Horn, 2000).

Given that there is general consensus among researchers who state that text composition involves a complex process of problem solving (Bruning \& Horn, 2000), one of the cognitive styles that should have greater influence on writing is reflexivity. Reflexivity refers to a person's analytic capacity when dealing with tasks which imply an uncertain response and require a hypothesis valuation in order to solve them (Smith \& Nelson, 1988; Solís-Cámera \& Servera, 2003).

Miras (2000) pointed out that some of the necessary writing abilities include the capacity and intention to question our own knowledge, the ability to identify confused and contradictory ideas, and to read strategically, and to re-read one's own written texts. These types of ability are only possible in the presence of a reflexive style.

This cognitive style seems to be related to academic achievement and learning capacity (Bornas \& Servera, 1996; Buela-Casal, Santos-Roig, \& Carretero, 2000) in addition to other cognitive functions (Amador \& Kirchner, 2001), and some researchers have identified a strong relationship between reflexivity and reading (Kagan, 1965b), writing (García \& de Caso, 2002b; Hansen, 1998; Munro \& Howes, 1998), and mathematics (Hershkowitz \& Schwartz, 1999). Gargallo $(1991,1993,1996)$ found that it is possible to modify this cognitive style in different samples of students (ranging from 7 to 14 years old), with a resulting improvement in their scores after the intervention. Therefore, one could say that there is greater potential for lifelong improvement as reflexivity is studied (Edwards, Ranson, \& Strain, 2002).

But does the level of learning improvement increase independently of the student's reflexivity level? Concerning team work, Barry, Britten, Barber, Bradley, and Stevenson (1999) have shown that a reflexive approach to writing may help the functioning and productivity of a team. Moreover, De Dreu (2002) discovered the presence of more innovation and greater team effectiveness under high rather than low levels of minority dissent, but only when there was a high level of team reflexivity. As writing requires a great amount of innovation and creativity, because one text is never the same as another, might high reflexivity levels promote greater quantity and quality compositions than low reflexivity levels?

Learning disabled (LD) students seem to have difficulties identifying, selecting and/or implementing strategies for preplanning, text generation and/or revising (Butler, 1998, 1999; Butler, Elaschuk, \& Poole, 2000; Graham, Harris, McArthur, \& Schwartz, 1998). Impulsive and reflexive children differ basically in the strategies they choose to solve problems, and the most appropriate strategies are those employed by reflexive children (Bornas, Servera, \& Llabrés, 1997). Therefore, training LD students to be more reflexive in their writing might encourage them to use better strategies when writing compositions. However, logically, depending on the student's reflexivity level, the intervention should focus on one aspect or another. Because of this, our aim is to show how reflexivity levels (low, medium, or high) influence a student's performance in composition writing tasks, and also to determine the extent to which training can improve performance depending on the LD students' reflexivity levels.

The hypotheses can be stated as follows:

1. After participation in a writing instructional program based on reflexivity, the improvement of the LD students' writing will depend on their reflexivity level.

2. After the participation in instructional program, in addition to composition writing, attitudes and selfefficacy will also improve to different degrees depending on the students' reflexivity level.

3. The reflexive variables will also improve to different degrees depending on students' reflexivity level.

4. As a result of the three previous hypotheses, the students' reflexivity level will influence the quality and productivity of their written compositions.

\section{Method}

\section{Participants}

Participants were 100 fifth- and sixth-grade primary school students, with LD and/or low achievement (LA) whose age ranged between 10 and 12 years old. All the participants had previously been identified by either a school psychologist or a teacher as having a writing-specific LD, excluding those students who had been diagnosed as having special educational needs, as their difficulties and retardation could be attributed to a physical or a sensory disability or a lack of schooling, not just an LD. This sample was drawn from thirty-one public and private primary schools in the North West of Spain, specifically, most of the schools were in León but also in Asturias, Valladolid, Palencia, and Madrid. 
Participants were randomly allocated to either an experimental group, where students were exposed to a specific training program in reflexive writing, or to a control group, where they just received normal classes. The experimental group eventually comprised $49 \mathrm{LD}$ and/ or LA students (30 males and 19 females) and the control group was composed of $51 \mathrm{LD}$ and/or LA students (29 males and 22 females).

\section{Instruments}

The participants from both groups, experimental and control, were assessed in aspects of text quality and productivity as well as in reflexivity, attitudes, and selfefficacy towards writing before and after the instruction program was applied to the students in the experimental group.

A battery of tests called "Evaluación de los Procesos de Planificación y otros Factores Psicológicos de la Escritura" (EPPyFPE) [Assessment of Writing Planning Processes and other Psychological Factors in Writing], developed by García, Marbán, and de Caso (2001) was administered. This assessment was validated in a sample of 1691 students ranging from 8 to 16 years old, obtaining a Cronbach's alpha of .856 (García \& Marbán, 2003), which indicates a very high level of internal consistency and shows that the instrument functions appropriately.

This battery involved the composition of three texts of increasing complexity: a descriptive text, a narrative text, and an essay (Cuetos, 1991). To evaluate the way the students composed these texts, various measures of productivity were taken, such as the number of content words (nouns, verbs, adverbs, adjectives, and interjections), the number of functional words (prepositions, pronouns, and conjunctions), and the number of determiners (articles). Indicators of text coherence (theme continuity, links between propositions, well organized and thematically delineated paragraphs, and consistent thread/plot of meaning throughout the text) and text structure in the narrative (frame indicators such as time, space, and characters, and episode indicator marks such as initial event, internal responses, actions, and consequences) were also collected.

The EPPyFPE includes a task where children must integrate different parts of information into a single proposition in order to see whether the students possess the ability to combine different ideas. The battery also contains two questionnaires about attitudes and self-efficacy towards writing that students have to complete; both are translated into Spanish and adapted from a scale developed and validated by Wong, Butler, Ficzere, and Kuperis (1996, 1997). The attitudinal questionnaire is comprised of 10 statements, such as "I like to write essays" or "I would rather read than write." The self-efficacy questionnaire is made up of 15 statements, such as "It is very easy for me to start to write an essay" or "It is difficult to me to check the spelling when writing an essay." In both these questionnaires, students must indicate whether or not they agree with each item, with also the possibility of responding "I don't know."

Lastly, the EPPyFPE includes three tasks that attempt to assess reflexivity towards writing. In the first one, "Estilos Cognitivos 1" (EC 1) [Cognitive Styles 1], students are given a series of words, some correctly written and others incorrectly written. The students' task is to identify the incorrectly written words and to write them correctly under the wrong version. They do not have to write anything under the correct words. For example, if students see "vlouse" they must correct the word and write "blouse," but if students read "ship," which is correct, they do not have to write anything. The following scores were collected; the number of mistakes (incorrect words that the children did not rewrite correctly or that they did not identify as being incorrect, and the correct words that they rewrote), the number of correct answers (incorrect words that students wrote correctly and correct words that they did not rewrite) and the amount of time taken to complete the entire task.

"Estilos Cognitivos 2" (EC 2) [Cognitive Styles 2] is another reflexivity task that complements the EC 1 . In this case, students must perform the same task as in EC 1, but they are only given one minute in which to complete the task, which is insufficient time for any student to finish the task. This time restriction therefore allowed the assessors to check how many correct answers and mistakes the students make (in 1 minute). Furthermore, the assessors could then check whether the students who achieve more correct answers use an appropriate search system to respond, which can be seen by analyzing the order in which the students answered.

The third task related to reflexivity consists of an spelling test, where students have to identify the correctly written word on a list where the same word is written in six different ways. This final task illustrates whether mistakes in the other two tasks are due to an impulsive style or whether they are due to the student's ignorance of the spelling rules.

Apart from the EPPyFPE, students were also assessed with three experimental instruments that were developed for this specific research project to appraise reflexivity towards writing, taking into account the frequency with which children use different words according to the vocabulary development and frequency dictionary of Justicia (1995). The first task was "Formación de Palabras con Letras" (W-L) [Making words with letters], in which the children were given series of 4 or 9 letters with which they should make words, using as many letters as possible. In the second task, Formación de Palabras con Sílabas (WSyl) [Making words with syllables], the children were given series of 3 or 5 syllables to form words and, finally, in the third task, Formación de Frases con Palabras (S-W) [Making sentences with words], the children were given series of 3 or 5 words with which they should form sentences. The time taken to complete the tasks was measured, as was the 
adaptation of the words and sentences formed, taking into account the number of letters, syllables, and words used. We also differentiated adaptation and the time the students spent over familiar words and adaptation and the time on unfamiliar words.

These three instruments were jointly validated in our sample, showing a Cronbach's alpha of .78, which indicates that these instruments function well conjointly. But even separately, they show adequate internal consistency as WL obtained a Cronbach's alpha of .67 and S-W a Cronbach's alpha of .70.

We decided not to use the Matching Familiar figures Test (MFF20) by Cairns and Cammock (1978), which traditionally measures reflexivity-impulsivity, as it is a general cognitive style instrument and does not measure the personality aspect related to writing that we required.

\section{Intervention Program}

A training program in writing via tasks to enhance reflexivity was developed specifically for the purposes of this research project. This program was designed following the process and text planning of Hayes and Nash (1996) to which the "Stop and Think" model of Kendall, Padever, and Zupan (1980) was added. The resulting training program targeted $5^{\text {th }}$ - and $6^{\text {th }}$-grade children, as the materials used were taken from activities and books that students of this age use regularly in their other lessons.

Firstly, the planning process of composition writing was trained in 25 sessions, each lasting between 45 and 55 minutes. In an initial session, the importance of the writing process was illustrated, and in a further 2 sessions, the students were specifically introduced to the Sorenson (1997) model of writing and the concept of reflexivity, adding Mather and Roberts' (1995) suggestions. The next 6 sessions were entirely dedicated to training the preparation processes of writing, which included aspects such as searching for information, establishing the purpose, analyzing the audience, the theme, establishing the thesis ( 2 sessions), and organizing the material. Sessions ten to thirteen involved specific training in editing and drafting, marking techniques of paragraph composition, using the yo-yo approach, and teaching the different types of textual structures and cohesive links. The final processes in Sorenson's (1997) writing model were taught during sessions fourteen and fifteen, in which students were trained in the revising processes of writing, not only dealing with spelling and grammatical issues but also with the revision of the structure and coherence. Sessions sixteen and seventeen comprised a review of the writing and revision processes that students had learnt in previous sessions. The remaining sessions, from eighteen to twenty-four, were dedicated to teaching three different types of composition: description, narration, and essay. The aim was to introduce the important features of the different writing genres that students are likely to be required to produce during their academic careers. The final session consisted of a review of the entire writing process, highlighting the need for reflexivity throughout it.

Secondly, text planning was integrated along with process planning, as it includes texts from students' books and other texts which the students have been producing through the intervention. This program involves three types of text planning, language, abstract and mixed. Graphic organizers or writing disks to organize an essay are examples of abstract text planning whereas self-instructional steps or selfquestioning cards are examples of language text planning. Examples of mixed text planning are filling in cards showing graphics with letters, such as the graphic organizer for writing a narrative text, which shows a doll whose eyes and mouth remind the students that they should include in the first paragraph whoever is involved and where and when the story takes place. The doll's arms indicate that the students must write whatever happened in the first place and the subsequent events in order, and finally, the doll's legs remind students to write a conclusion at the end of the narration (see Figure 1).

Finally, reflexivity was trained from the beginning of the writing program. In the first session, the instructor gave the students a stop sign with Meichenbaum and Goodman's (1971) self-instructional steps of problem definition, problem

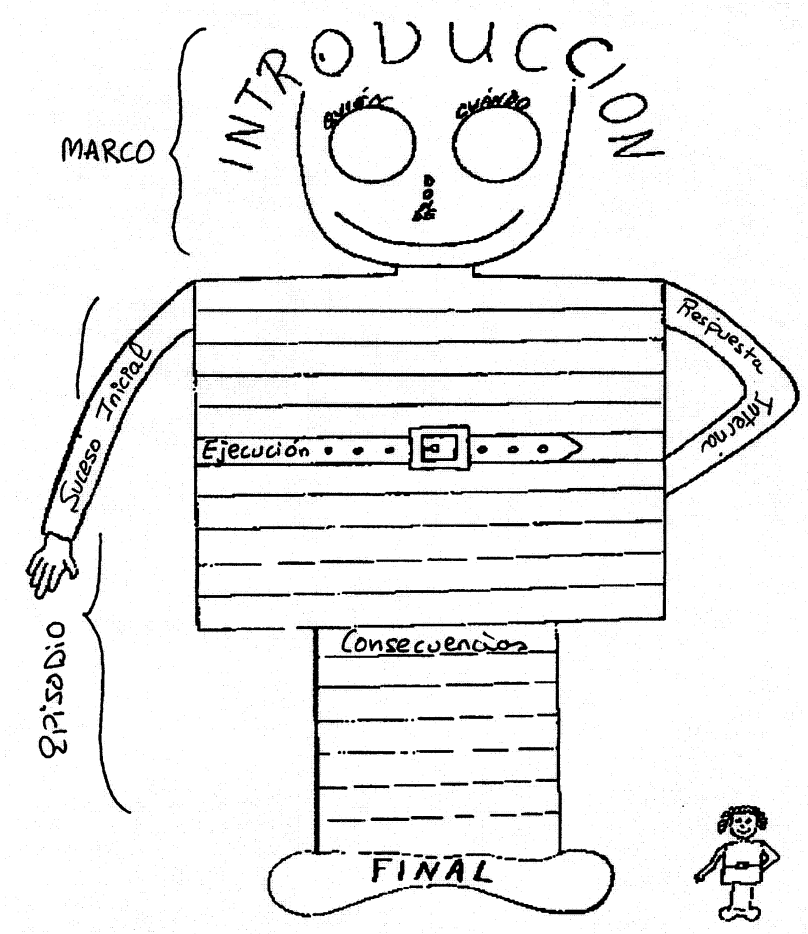

Figure 1. Example of mixed text planning: graphic organizer to write a narrative text (translated and adapted from Mather \& Roberts, 1995, p. 179) 
approximation, focalization of attention, response selection, self-assessment, and self-reinforcement or rectifying mistakes. Throughout each task that the students had to accomplish during the whole program, the instructor reminded them to work taking into account the stop sign and the Stop and Think model of Kendall et al. (1980). This meant that the instructor had to remind the students to pause at the beginning of a new activity, listen to the teacher and see how to complete the task, then consider the best option to provide the answer and, finally they must carry out the task. As the students completed a specific activity, they had to say aloud each of the steps they were already following and they had to use the appropriate self-instructions in order to fulfill the task. All the students received social reinforcement from the instructor after accomplishing their activities successfully.

\section{Research Planning and Design}

Firstly, in order to confirm the initial homogeneity of both groups (control and experimental) at pretest, so that any posttest differences would be due to the instructional program, variance of analysis was carried out as well as analysis of covariance of the posttest measures, with the corresponding pretest scores as covariate for each variable.

Secondly, the present research project has an quasiexperimental design, in which we used a $2 \times 3$ (Group $\times$ Reflexivity) factorial analysis. The two group values were control and experimental. The reflexivity factors had three levels (1, 2 and 3), as a function of the experimental scales, which were obtained with $k$-means cluster analysis.

To differentiate the students' reflexivity levels, each of the reflexivity variables of the two kinds of instruments that measure reflexive style were used. Firstly, students' reflexivity levels according to EC 1 and EC 2 scores were differentiated, and subsequently, the reflexivity level was differentiated according to their scores in W-L, W-Syl, and S-W. All the students had to complete both instruments, so we differentiated reflexivity levels twice, depending on the instrument, but the sample was always the same; only the grouping factor varied.

\section{Procedure}

The intervention was delivered by 31 teachers who were also in their final year of a Master's course in psychology and pedagogy. These teachers were trained not only in the application of the assessment instruments but also in the instructional program in order to ensure a homogeneous assessment and intervention in which all the instructors adopt the same criteria.

After the teachers' training, the sample of LD and/or LA students described above was selected, and the participants were randomly assigned to either the control or experimental group. Then the pretests were conducted in both groups by the teachers in small groups of between two and six children.

Once this initial assessment was carried out, the next step was to train the experimental participants during March, April, and May of 2001. The program was administered in their normal school setting but as an out-of-school activity, at a rate of three or four sessions per week but never with two sessions on the same day. The training was conducted in small groups of two or three children in order to attend to the individual student's differences. During this time, students in the control group continued with their regular lessons at their schools.

After the participants in the experimental group were exposed to 25 sessions of training, both the intervention and control groups completed the posttest assessment, which comprised the same instruments and was delivered in the same way and by the same teachers as the pretest. It is noteworthy that students in the control group were assessed by the same teachers as students in the experimental one, so that assessment was conducted in the same way for all participants.

\section{Results}

Once the data were encoded, analysis of variance was carried out to establish the homogeneity of the control and the experimental groups at pretest. Significant differences were found only in 5 of the 36 writing variables, and in 6 of the 22 reflexivity variables. Generally, these significant differences were in favor of the control group.

The results of the analysis of covariance are displayed in Table 1, where it can be seen that there are more statistically significant group differences in the writing variables than in the reflexive variables.

The transformed variables in the three clusters resulting from the $k$-means cluster analysis were used as grouping variables that were one of the factors used in the multivariate general lineal models analysis. The other factor used in this analysis was the group (experimental or the control). The remaining variables (text quality and productivity, attitudes and self-efficacy towards writing, and writing reflexivity) were the dependent variables. For these analyses, we only used the variables that refer to total aspects of writing in order to organize and present the most relevant information.

The pretest analysis of variance showed that both groups were initially equivalent, as no statistically significant differences were revealed in the writing tasks and attitudinal and self-efficacy questionnaires, for example, for reflexivity levels obtained in EC $1(p>.05)$, or for reflexivity levels obtained in W-L $(p>.05)$. Thus, any posttest group differences in reflexivity levels could be a result of the intervention. 
Table 1

Results of Analysis of Covariance of Pre- and Posttest Measures

\begin{tabular}{|c|c|c|c|c|c|c|c|}
\hline \multirow{2}{*}{\multicolumn{2}{|c|}{ Variable }} & \multicolumn{2}{|c|}{$\begin{array}{l}\text { Control Group } \\
(n=50)\end{array}$} & \multicolumn{2}{|c|}{$\begin{array}{l}\text { Experimental Group } \\
\qquad(n=49)\end{array}$} & \multirow[b]{2}{*}{$F(1,96)$} & \multirow[b]{2}{*}{$p$} \\
\hline & & Pretest & Posttest & Pretest & Posttest & & \\
\hline \multirow{7}{*}{ 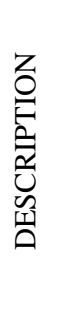 } & Content words & 17.55 & 17.86 & 19.24 & 25.48 & 17.11 & .001 \\
\hline & Functional words & 7.69 & 7.5 & 8.61 & 10.41 & 9.3 & .003 \\
\hline & Determinants & 9.63 & 10.06 & 11.10 & 12.92 & 7.83 & .006 \\
\hline & Total words & 36.37 & 35.5 & 38.39 & 48.14 & 11.7 & .001 \\
\hline & Pertinence & 0.98 & 0.98 & 0.94 & 0.88 & 4.31 & .041 \\
\hline & Paragraphs & 0.18 & 0.22 & 0.18 & 0.55 & 12.5 & .001 \\
\hline & Total coherence & 2.65 & 2.76 & 2.29 & 3.02 & 3.32 & .072 \\
\hline \multirow{9}{*}{ 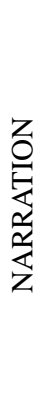 } & Content words & 48.69 & 42.12 & 41.37 & 48.43 & 7.0 & .009 \\
\hline & Functional words & 30.25 & 24.66 & 28.27 & 27.92 & 3.2 & .077 \\
\hline & Total words & 102.84 & 85.62 & 90.37 & 98.03 & 6.32 & .014 \\
\hline & Structure: time & 0.45 & 0.42 & 0.39 & 0.55 & 3.28 & .073 \\
\hline & Structure: Space & 0.59 & 0.54 & 0.43 & 0.71 & 3.73 & .056 \\
\hline & Structure: Execution & 0.86 & 0.86 & 0.78 & 0.98 & 5.85 & .017 \\
\hline & Total structure & 5.14 & 5.14 & 4.59 & 5.67 & 7.59 & .007 \\
\hline & Paragraphs & 0.29 & 0.38 & 0.2 & 0.65 & 10.8 & .001 \\
\hline & Total coherence & 2.73 & 2.96 & 2.59 & 3.41 & 8.14 & .005 \\
\hline \multirow{6}{*}{$\begin{array}{l}\text { 空 } \\
\text { 心ి } \\
\text { II }\end{array}$} & Content words & 29.94 & 23.38 & 26.39 & 31.21 & 17.37 & .001 \\
\hline & Functional words & 16.86 & 12.5 & 15.02 & 15.94 & 6.38 & .013 \\
\hline & Determinants & 11.24 & 9.12 & 9.67 & 11.71 & 8.62 & .004 \\
\hline & Total words & 58.24 & 45.46 & 51.06 & 57.65 & 11.86 & .001 \\
\hline & Paragraphs & 0.33 & 0.32 & 0.29 & 0.55 & 7.16 & .009 \\
\hline & Total coherence & 2.38 & 2.84 & 2.33 & 3.16 & 7.89 & .006 \\
\hline \multicolumn{2}{|c|}{ Attitude item 3} & 1.63 & 1.52 & 1.65 & 1.83 & 4.05 & .047 \\
\hline \multicolumn{2}{|c|}{ Attitude item 4} & 2.25 & 1.94 & 1.78 & 2.14 & 5.72 & .019 \\
\hline \multicolumn{2}{|c|}{ Attitude item 9} & 2.16 & 2.46 & 2.12 & 2.12 & 4.17 & .044 \\
\hline \multicolumn{2}{|c|}{ Total attitude } & 21.39 & 20.72 & 20.29 & 21.55 & 3.2 & .077 \\
\hline \multicolumn{2}{|c|}{ Self-efficacy item 4} & 2.24 & 2.42 & 2.10 & 2.06 & 3.45 & .066 \\
\hline \multicolumn{2}{|c|}{ Total score in EC 2} & 6.38 & 8.87 & 6.70 & 7.44 & 6.48 & .013 \\
\hline \multicolumn{2}{|c|}{ Total score in W-L } & 27.67 & 30.4 & 25.27 & 31.27 & 3.14 & .079 \\
\hline
\end{tabular}

Note. Only the statistically significant $(p<.05)$ or nearly significant $(p<.099)$ present results are presented.

After the general lineal model analysis with posttest measures was performed, the multivariate contrasts revealed statistically significant differences in the number of mistakes students made in EC 2 task, $F(1,128)=1.503, p=.041$, $\eta^{2}=.341$, and in the total time students spent on the P-F task, $F(1,128)=1.558, p=.029, \eta^{2}=.349$, and nearly statistically significant differences in the time students spent completing the EC 1 task, $F(1,130)=1.447, p=.06, \eta^{2}=$ .319 , and in the total time spent carrying out the L-P task, $F(1,128)=1.408, p=.07, \eta^{2}=.326$. There were no significant difference when using other variables to establish reflexivity levels.

In the rest of this section, we are going to present the between-subject effect and the post hoc contrast of the analyses that revealed statistically significant differences. The data is organized in three parts, concerning the texts (quality and productivity), attitudes and self-efficacy towards writing and reflexivity towards writing.

\section{Text Quality and Productivity}

After ensuring that the significant group differences depended on students' reflexivity levels, the intersubject effects of the interaction were analyzed, finding statistically or nearly statistically significant group differences in the writing variables shown in Table 2. 
Table 2

Results in Text Quality and Productivity from the $2 \times 3$ K-Means Cluster Analysis (2 Groups: Control and Experimental $\times 3$ Reflexivity Levels)

\section{REFLEXIVITY LEVELS ACCORDING TO TIME SPENT IN EC 1}

\begin{tabular}{|c|c|c|c|c|c|c|c|c|c|}
\hline \multirow[t]{2}{*}{ Variables } & \multicolumn{3}{|c|}{$\begin{array}{c}\text { Control Group } \\
\text { Reflexivity Levels } \\
M\end{array}$} & \multicolumn{3}{|c|}{$\begin{array}{c}\text { Experimental Group } \\
\text { Reflexivity Levels } \\
M\end{array}$} & \multirow[b]{2}{*}{$F(2,128)$} & \multirow[b]{2}{*}{$p$} & \multirow[b]{2}{*}{$\eta^{2}$} \\
\hline & 1 & 2 & 3 & 1 & 2 & 3 & & & \\
\hline Total productivity in narration & 88.94 & 77.54 & 92.73 & 124.92 & 94.42 & 83.23 & 2.53 & .086 & .06 \\
\hline Total structure in narration & 5.92 & 5.58 & 5.6 & 5.93 & 5.03 & 5.23 & 2.73 & .071 & .06 \\
\hline \multicolumn{10}{|c|}{ REFLEXIVITY LEVELS ACCORDING TO ERRORS IN EC 2} \\
\hline Total coherence in description & 3.09 & 2.7 & 2.17 & 2.83 & 3.6 & 2.83 & 3.47 & .035 & .08 \\
\hline Total coherence in narration & 3.35 & 2.9 & 2.33 & 3.42 & 3.3 & 3.42 & 2.57 & .083 & .06 \\
\hline Total structure/coherence & 11.83 & 9.7 & 9.17 & 11.75 & 12.9 & 11 & 4.38 & .015 & .09 \\
\hline \multicolumn{10}{|c|}{ REFLEXIVITY LEVELS ACCORDING TO TIME SPENT IN S-W } \\
\hline Total productivity in narration & 108.87 & 67 & 87.62 & 95.8 & 113.6 & 87.56 & 5.33 & .007 & .11 \\
\hline Total coherence in narration & 3.4 & 2.88 & 2.62 & 3 & 3.6 & 3.56 & 4.84 & .01 & .1 \\
\hline Total coherence in essay & 3.07 & 3 & 2.23 & 2.8 & 3.2 & 3.38 & 4.35 & .016 & .09 \\
\hline Total productivity & 198.13 & 142 & 159 & 207.53 & 219.4 & 187.25 & 2.74 & .07 & .06 \\
\hline Total structure/coherence & 11.8 & 10.53 & 9.46 & 11.4 & 12 & 12 & 3.1 & .05 & .07 \\
\hline Total planning & 218 & 160.82 & 176.85 & 227.6 & 239.73 & 207.81 & 2.7 & .7 & $.06^{*}$ \\
\hline
\end{tabular}

Note. Only the statistically significant $(p<.05)$ or nearly significant $(p<.099)$ present results are presented.

$\eta^{2}=$ estimates of effect size. Cohen's (1988) rule states that values of $\eta^{2}$ between .01 and .06 indicate a small effect; values higher than .06 up to .14 indicate a medium effect; and values higher than .14 indicate a large effect.

By analyzing only the totals of the different writing aspects, we observed that the instructional program helped to improve text quality and productivity of the narrative texts more than the descriptive texts or the essays, as we found five narrative text variables with statistically or nearly significant differences between the participants in the control group and those in the experimental group. The students in the $2^{\text {nd }}$ reflexivity level improved their narration productivity and coherence more than the participants in the $1^{\text {st }}$ or $3^{\text {rd }}$ reflexivity levels, even taking into account that the participants of level 3 also improved their narrative coherence.

As regards the descriptive text and the essay, we only found statistically significant differences in the total coherence of each type of text, and the participants in the $2^{\text {nd }}$ and $3^{\text {rd }}$ reflexivity levels groups seemed to benefit more from the instructional program. No differences were found in productivity.

Lastly, it is noteworthy that there were significant differences in total planning, which illustrates the direction of the improvement of all the reflexivity levels, although the $2^{\text {nd }}$ level showed the greatest improvement. The etasquared statistic, which estimates the effect size, indicates that most of the variables had a medium effect size, as their values were between .06 and .14.

Post hoc contrasts between pairs of levels of reflexivity $\left(1^{\text {st }}, 2^{\text {nd }}\right.$, and $\left.3^{\text {rd }}\right)$, revealed statistically significant or nearly significant differences between the $1^{\text {st }}$ and $2^{\text {nd }}$ reflexivity levels $(p=.01)$ and between the $1^{\text {st }}$ and $3^{\text {rd }}$ levels $(p=.065)$ in total structure in narrative texts; between the $1^{\text {st }}$ and $3^{\text {rd }}$ levels $(p=.08)$ in total coherence in narrative texts; between the $2^{\text {nd }}$ and $3^{\text {rd }}$ levels $(p=.079)$ in total coherence in descriptive texts; between the $1^{\text {st }}$ and $3^{\text {rd }}$ levels $(p=.06)$ and between the $2^{\text {nd }}$ and $3^{\text {rd }}$ levels $(p=.033)$ in total coherence in the essay texts; and finally, between the $1^{\text {st }}$ and $3^{\text {rd }}$ levels $(p=.01)$ in total structure/coherence planning.

\section{Attitudes and Self-efficacy towards Writing}

When analyzing the total scores from the attitudinal and self-efficacy questionnaires, we found statistically significant or nearly significant differences in the total of attitudes when using three of the four grouping variables, as shown in Table 3. However, we only found statistically significant differences in the writing self-efficacy totals when using the total time students spent on the S-W task. 
Table 3

Results in Attitudes and Self-Efficacy towards Writing from the $2 \times 3$ K-Means Cluster Analysis (2 Groups: Control and Experimental $\times 3$ Reflexivity Levels)

REFLEXIVITY LEVELS ACCORDING TO TIME SPENT IN EC 2

\begin{tabular}{|c|c|c|c|c|c|c|c|c|c|}
\hline \multirow[t]{2}{*}{ Variables } & \multicolumn{3}{|c|}{$\begin{array}{c}\text { Control Group } \\
\text { Reflexivity Levels } \\
M\end{array}$} & \multicolumn{3}{|c|}{$\begin{array}{c}\text { Experimental Group } \\
\text { Reflexivity Levels } \\
M\end{array}$} & \multirow[b]{2}{*}{$F(2,128)$} & \multirow[b]{2}{*}{$p$} & \multirow[b]{2}{*}{$\eta$} \\
\hline & 1 & 2 & 3 & 1 & 2 & 3 & & & \\
\hline Total writing attitudes & 20.52 & 19.4 & 22.33 & 22.75 & 20.90 & 19.08 & 3.2 & .046 & .07 \\
\hline \multicolumn{10}{|c|}{ REFLEXIVITY LEVELS ACCORDING TO TIME SPENT IN W-L } \\
\hline Total writing attitudes & 22.29 & 20.79 & 18.92 & 20 & 22.11 & 22.14 & 2.96 & .057 & .07 \\
\hline \multicolumn{10}{|c|}{ REFLEXIVITY LEVELS ACCORDING TO TIME SPENT IN S-W } \\
\hline Total writing attitudes & 22 & 21.65 & 18.15 & 19.67 & 22.8 & 21.69 & 3.39 & .038 & .07 \\
\hline Total writing self-efficacy & 33.8 & 32.29 & 27.23 & 28 & 31 & 32.56 & 7.26 & .001 & .15 \\
\hline
\end{tabular}

Note. Only the statistically significant $(p<.05)$ or nearly significant $(p<.099)$ present results are presented.

$\eta^{2}=$ estimates of effect size. Cohen's (1988) rule states that values of $\eta^{2}$ between .01 and .06 indicate a small effect; values higher than .06 up to .14 indicate a medium effect; and values higher than .14 indicate a large effect.

Table 4

Results in Reflexivity Towards Writing from the $2 \times 3$ K-Means Cluster Analysis (2 Groups: Control and Experimental $\times 3$ Reflexivity Levels)

REFLEXIVITY LEVELS ACCORDING TO TIME SPENT IN EC 1

\begin{tabular}{|c|c|c|c|c|c|c|c|c|c|}
\hline \multirow[t]{2}{*}{ Variables } & \multicolumn{3}{|c|}{$\begin{array}{c}\text { Control Group } \\
\text { Reflexivity Levels } \\
M\end{array}$} & \multicolumn{3}{|c|}{$\begin{array}{l}\text { Experimental Group } \\
\text { Reflexivity Levels } \\
M\end{array}$} & \multirow[b]{2}{*}{$F(2,128)$} & \multirow[b]{2}{*}{$p$} & \multirow[b]{2}{*}{$\eta^{2}$} \\
\hline & 1 & 2 & 3 & 1 & 2 & 3 & & & \\
\hline Total W-Syl score & 41.18 & 36.38 & 41.53 & 43.75 & 42.68 & 36.87 & 2.99 & .056 & .07 \\
\hline \multicolumn{10}{|c|}{ REFLEXIVITY LEVELS ACCORDING TO ERRORS IN EC 2} \\
\hline Search system in EC 2 & 4.74 & 3.5 & 4 & 4 & 5 & 3.5 & 5.67 & .005 & .12 \\
\hline Total time in S-W & 496.52 & 516.7 & 606.58 & 611.5 & 576.8 & 509.83 & 2.96 & .057 & .07 \\
\hline
\end{tabular}

REFLEXIVITY LEVELS ACCORDING TO TIME SPENT IN W-L

\begin{tabular}{lrrrrrrrrr}
\hline Total correct answers in EC 2 & 8.57 & 7.58 & 11.67 & 8.75 & 6.78 & 6.71 & 3.95 & .023 & .09 \\
\hline \multicolumn{7}{c}{ REFLEXIVITY LEVELS ACCORDING TO TIME SPENT IN S-W } \\
\hline Total errors in EC 2 & 0.2 & 1.59 & 1.31 & 1.4 & 1 & 0.63 & 4.25 & .017 & .09 \\
Total time in S-W & 391.8 & 529.12 & 691.85 & 384.67 & 534.13 & 798.75 & 3.24 & .044 & .07 \\
\hline
\end{tabular}

Note. Only statistically significant $(p<.05)$ or nearly significant $(p<.099)$ results are presented.

$\eta^{2}=$ estimates of effect size. Cohen's (1988) rule states that values of $\eta^{2}$ between .01 and .06 indicate a small effect; values higher than .06 up to .14 indicate a medium effect; and values higher than .14 indicate a large effect. 
Once again, the participants in the $2^{\text {nd }}$ reflexivity level seem to be those who benefited the most from the training program, as they consistently improved their scores in attitudes and self-efficacy towards writing in contrast to the students in the $1^{\text {st }}$ reflexivity level, who showed no improvement or even showed a decrease in their scores on these two variables.

Taking into account the effect size, all eta-squared statistics had values between .06 and .14, which implies a medium size effect in each variable except for self-efficacy, whose value was even larger.

Analyzing the post hoc contrast in each design, we found no statistically significant differences between the two specific groups (experimental and control), but when considering the three reflexivity levels conjointly, in the intersubject effects, we found differences, as shown in Table 2.

\section{Reflexivity towards Writing}

As regards the reflexive dependent variables and the group differences, reflexivity levels showed some statistically or nearly statistically significant differences, as shown in Table 4.

As for text quality and productivity variables, and attitudes and the self-efficacy variables, systematically, the students from the $2^{\text {nd }}$ reflexivity level showed significantly higher scores after the instructional program than their peers from the other two reflexivity levels. Even when considering the mistakes, participants of this $2^{\text {nd }}$ level reduced their errors, thus reaching reflexivity level 3 after the intervention. It is also noteworthy that the experimental participants from the $1^{\text {st }}$ reflexivity level were those who improved the least after training, and their scores even deteriorated in some variables compared to their control peers. Once again, the eta-squared statistic indicated that most of the variables had a medium effect size, as this value was between .06 and .14.

Lastly, post hoc tests were performed on these reflexive variables, revealing statistically significant differences using each of the grouping variables (time spent in EC 1, mistakes in EC 2, time spent in W-L, and time spent in S-W) except for errors in EC 2. When using reflexivity levels established by time spent in EC 1, we found statistically significant differences in the correct answers in EC 1 between the $2^{\text {nd }}$ and $3^{\text {rd }}$ reflexivity levels $(p=.035)$; between the $1^{\text {st }}$ and $3^{\text {rd }}$ levels $(p=.005)$ and between the $2^{\text {nd }}$ and $3^{\text {rd }}$ levels $(p=$ 0.038) in errors in EC 1; between the $1^{\text {st }}$ and $2^{\text {nd }}$ levels (p $=0.085)$ and between the $1^{\text {st }}$ and $3^{\text {rd }}$ levels $(p=.025)$ in correct answers in EC 2; between the $1^{\text {st }}$ and $3^{\text {rd }}$ levels $(p$ $=.026)$ in time spent in W-Syl; and between the $1^{\text {st }}$ and $3^{\text {rd }}$ levels $(p=.03)$ in time spent in S-W. Using time spent in $\mathrm{W}-\mathrm{L}$ as the grouping variable, we found statistically significant differences between the $1^{\text {st }}$ and $3^{\text {rd }}$ levels $(p=$ .021 ) in total time spent on W-Syl; between the $2^{\text {nd }}$ and $3^{\text {rd }}$ levels $(p=.06)$ in total score in W-Syl; and between the $1^{\text {st }}$ and $3^{\text {rd }}$ levels $(p=.001)$ in total time on S-W. Finally, using time spent in S-W as the grouping variable, we found statistically significant differences between the $1^{\text {st }}$ and $3^{\text {rd }}$ levels $(p=.001)$, and between the $2^{\text {nd }}$ and $3^{\text {rd }}$ levels ( $p=$ $.004)$ in time spent $\mathrm{n} \mathrm{W}-\mathrm{L}$, and between the $1^{\text {st }}$ and $3^{\text {rd }}$ levels $(p=.001)$ and the $2^{\text {nd }}$ and $3^{\text {rd }}$ levels $(p=.001)$ in time spent on W-Syl.

\section{Discussion}

The aim of this study was to contrast the way LD and/or LA students' reflexivity levels influence their composition writing and how their attitudes, self-efficacy and reflexivity towards writing change after training in an instructional writing program based on reflexivity. Our findings suggest that specific training in writing and reflexivity will improve the performance of LD and/or LA students. However the extent of the influence on the students' attitudes and selfefficacy towards writing remains unclear. Therefore, it can be stated that the initial hypotheses were only partially confirmed.

With regard to our first hypothesis, which suggested that LD students' written compositions would improve variably depending on their reflexivity levels, this was systematically true for narrative texts, as this kind of text showed the greatest statistically significant group differences in productivity, coherence, and structure. The scores for the descriptive and essay texts only changed significantly in coherence but not in productivity. We wish to highlight that these two kinds of texts were not exposed to measures of structure. This suggests that an explicit instructional writing program based on reflexivity is useful to teach students how to write, and teachers can employ Sorenson's (1997) writing model to accomplish this. Our findings confirm those of other instructional programs applied, such as that of García and Marbán (2003) or García and de Caso (2004, 2006).

The second initial hypothesis, which stated that attitudes and self-efficacy towards writing would improve as a function of student's reflexivity level, was also partially confirmed, as we obtained statistically significant intersubject differences among the three reflexivity levels of participants, but no group differences in the post hoc analysis were found. This result can be explained by the nature of our training, as we only trained in writing and reflexivity but not in any motivational aspect of writing. Therefore, our findings are consistent with other writing instructions that did not seek to modify attitudes or self-efficacy, such as those of Wong et al. (1996, 1997) or Page-Voth and Graham (1999). Specific training programs designed to modify these components have obtained different results, such as those of García and de Caso (2004) in attitudes towards writing or those of García and de Caso (2006) in self-efficacy towards writing.

However, we point out the need to consider students' reflexivity levels when implementing an intervention 
program, as no differences in attitudes and self-efficacy were observed in the group as a whole (García \& de Caso, 2002a, 2002b), but if students are differentiated by their reflexivity levels, such differences begin to appear, at least in the multivariate contrast and intersubject effect. This effect is logical, as one student's improvement is offset by another student's decline, so what one should observe is the link between students who improve and students who do not, and, in this case, this seems to be the reflexivity level.

Although Kagan (1965a, 1965b) defined a reflexiveimpulsive cognitive style as a person's relatively stable characteristic, we found differences between participants in the control and the experimental groups depending on their reflexivity levels, so that, in some variables of reflexivity, participants who initially had lower levels of reflexivity benefited more from the instruction, as they improved their scores of correct answers, fewer mistakes and more time spent on accomplishing the task. This finding is consistent with the initial research projects on this cognitive style by Gargallo (1996) or other researchers, such as Hershokowitz and Schwarz (1999), who have found differences in this construct after intervention programs of greater duration.

Finally, the fourth hypothesis seems to be confirmed, as we found differences in text productivity, structure, and coherence, which implies that the reflexivity level influences the writing of students with LD.

In this research project, we have shown how a reflexivity-based writing intervention program chiefly helps to improve the writing quality (as all kinds of texts improved in coherence) and the reflexive style of LD and/or LA students with a low reflexivity level, whereas it did not clearly change their attitudes and self-efficacy towards writing. This shows that the same program may be beneficial for some students and ineffective for others, and thus supports the argument that training programs should be individually designed, according to the student's cognitive style (Riding \& Agrell, 1997; Riding \& Watts, 1997) and such programs must train the student's specific aspects that suggest that instructions must be contextualized.

\section{References}

Alamargot, D., \& Chanquoy, L. (2001) Through the models of writing. Dordrecht, Holland: Kluwer Academic Publishers.

Amador, J.A., \& Kirchenr, T. (2001). Children's Embedded Figures Test and Matching Familiar Figures Test-20: Factorial structure for boys and girls from 6 to 11 years old. Perceptual and Motor Skills, 93, 709-712.

Barry, C.A., Britten, N., Barber, N., Bradley, C., \& Stevenson, F. (1999). Using reflexivity to optimize teamwork in qualitative research. Qualitative health research, 9, 26-44.

Bornas, X., \& Servera, M. (1996). La impulsividad infantil. Madrid: Siglo XXI.
Bornas, X., Servera, M., \& Llabrés, J. (1997). Prevención de la impulsividad y comportamiento estratégico en preescolares. Psicología Conductual, 5, 133-146.

Bruning, R., \& Horn, C. (2000). Developing motivation to write. Educational Psychologist, 35, 25-37

Buela-Casal, G., Santos-Roig, M., \& Carretero, H. (2000). Reflexividad frente a impulsividad en el rendimiento académico: un estudio longitudinal. Análisis y Modificación de Conducta, 26, 555-583.

Butler, D.L. (1998). Metacognition and learning disabilities. In B.Y.L. Wong (Ed.), Learning about learning disabilities $\left(2^{\text {nd }}\right.$ ed.) (pp. 277-307). Toronto: Academic Press.

Butler, D.L. (1999, April). The importance of explicit writing instruction for postsecondary students with learning disabilities. Paper presented at the annual meetings of the Council for Exceptional Children. Charlotte, North Carolina.

Butler, D.L., Elaschuk, C.L., \& Poole, S. (2000). Promoting strategic writing by postsecondary students with learning disabilities: A report of three case studies. Learning Disability Quarterly, 23, 196-213.

Cains, F.D. \& Cammock, J. (1978). Development of a more reliable version of the Matching Familiar Figures Test. Developmental Psychology, 5, 555-560.

Cuetos, F. (1991). Psicología de la escritura. Madrid: Escuela Española.

De Dreu, C. (2002). Team innovation and team effectiveness: The importance of minority dissent and reflexivity. European Journal of Work and Organizational Psychology, 11, 285-298.

Edwards, R., Ranson, S., \& Strain, M. (2002). Reflexivity: Towards a theory of lifelong learning. International Journal of Lifelong Education, 21, 525-536.

Flower, L., \& Hayes, J.R. (1981). Plans that guide the composing process. In C.H. Frederiksen \& J.F. Dominic (Eds.), The nature, development and teaching of written communication. Vol. 2. Writing: Process. Development and communication (pp. 3958). Hillsdale, NJ: Erlbaum.

García, J.N., \& de Caso, A.M. (2002a). Estrategias cognitivas en la composición escrita: ilustración de un programa de intervención. In J.A. González-Pienda, J.C. Núñez, L. Alvárez, \& E. Soler (Coords.), Estrategias de aprendizaje: concepto, evaluación e intervención (pp. 141-162). Madrid: Pirámide.

García, J.N., \& de Caso, A.M. (2002b). ¿Es posible mejorar la composición en alumnos con dificultades de aprendizaje y/o bajo rendimiento sin que cambie la reflexividad hacia la escritura? Psicothema, 14, 456-462.

García, J.N., \& de Caso, A.M. (2004). Effects of motivational intervention for improving the writing of children with learning disabilities. Learning Disability Quarterly, 27, 141-159.

García, J.N., \& de Caso, A. .M. (2006). Changes in writing selfefficacy and writing products and processes through specific training in the self-efficacy beliefs of the learning disabled. Learning Disabilities: A Contemporary Journal, 4, 1-27.

García, J.N., \& Marban, J.M. (2003). El proceso de composición escrita en alumnos con DA y/o BR: estudio instruccional con énfasis en la planificación. Infancia y Aprendizaje, 26, 97-113. 
García, J.N., Marbán, J.M., \& de Caso, A.M. (2001). Evaluación colectiva de los procesos de planificación y factores psicológicos en la escritura. In J.N. García, Dificultades de aprendizaje e intervención psicopedagógica (pp. 151-155). Barcelona: Ariel.

Gargallo, B. (1991). Los procesos cognitivos y el aprendizaje. La reflexividad-impulsividad y el rendimiento académico. $P A D^{\prime} E$, $1,119-134$.

Gargallo, B. (1993). ¿Es posible modificar la impulsividad en el aula?. Programas de acción educativa. Revista de Educación, 301, 245-268.

Gargallo, B. (1996). La intervencion pedagogica en el ámbito de la reflexividad. Un programa educativo para $2^{\circ}$ de primaria. Bordón, 48), 225-238.

Graham, S., Harris, K.R., McArthur, C., \& Schwartz, S. (1998). Writing instruction. In B.Y.L. Wong (Ed.), Learning about learning disabilities ( $2^{\text {nd }}$ ed.) (pp. 391-423). Toronto: Academic Press.

Hansen, B. (1998). Using reflective portfolios as a tool to teach writing to students with learning disabilities: A project for preservice teachers. Reading \& Writing Quarterly, 14, 307318.

Hayes, J.R. (1996). A new framework for understanding cognition and affect in writing. In C.M. Levy \& S. Ransdell (Eds.), The science of writing. Theories, methods, individual differences and applications (pp. 1-27). Mahwah, NJ: Erlbaum.

Hayes, J.R., \& Nash, J.G. (1996). On the nature of planning in writing. In C.M. Levy \& S. Ransdell (Eds.), The science of writing. Theories, methods, individual differences and applications (pp. 29-55). Mahwah, NJ: Erlbaum.

Hershkowitz, R., \& Schwarz, B. (1999). Reflective processes in a mathematics classroom with a rich learning environment. Cognition and Instruction, 17, 65-91.

Justicia, F. (1995). El desarrollo del vocabulario. Diccionario de frecuencias. Granada, Spain: Servicio de Publicaciones de la Universidad de Granada.

Kagan, J. (1965a). Developmental studies in reflection and analysis. In A.H. Kidd \& J.H. Rivoire (Eds.), Conceptual development in children (pp. 487-522). New York: International University Press.

Kagan, J (1965b). Reflection-impulsivity and reading ability in primary grade children. Child Development, 36, 609-628.

Kellogg, R.T. (1994). The psychology of writing. New York: Oxford University Press.

Kendall, P.C., Padever, W., \& Zupan, B. (1980). Developing selfcontrol in children. A manual of cognitive-behavioural strategies. Minneapolis, MN: University of Minnesota.
Mather, N., \& Roberts, R. (1995). Informal assessment and instruction in written language: A practitioner's guide for students with learning disabilities. New York: Wiley.

Meichembaum, D., \& Goodman, J. (1971). Training impulsive children to talk to themselves. A means of developing selfcontrol. Journal of Abnormal Psychology, 77, 115-126.

Miras, M. (2000). La escritura reflexiva. Aprender a escribir y aprender acerca de lo que se escribe. Infancia y Aprendizaje, $89,65-80$

Page-Voth, V., \& Graham, S. (1999): Effects of goal setting and strategy use on writing performance and self-efficacy of students with writing and learning problems. Journal of Educational Psychology, 91, 230-240.

Munro, J., \& Howes, D. (1998). The effect of cognitive style on learning to write a letter of complaint. British Journal of Educational Psychology, 68, 243-254.

Riding, R., \& Agrell, T. (1997). The effect of cognitive style and cognitive skills on school subject performance. Educational Studies, 23, 311-323.

Riding, R., \& Al-Sanabani, S. (1998). The effect of cognitive style, age, gender and structure on the recall of prose passages. International Journal of Educational Research, 29, 173-185.

Riding, R., \& Rayner, S. (1998): Cognitive styles and learning strategies. London: David Fulton.

Riding, R., \& Watts, M. (1997). The effect of cognitive style on the preferred format of instructional material. Educational Psychology, 17, 179-183.

Smith, J.D., \& Nelson, D.G.K. (1988). Is the more impulsive child a more holistic processor? A reconsideration. Child Development, 59, 719-727.

Solís-Cámara, P., \& Servera, M. (2003). Los efectos del modelo probabilística sobre el estilo cognitivo reflexividad-impulsividad. Psicothema, 15, 545-549.

Sorenson, S. (1997). Students' writing handbook ( $2^{\text {nd }}$ ed.). New York: MacMillan.

Wong, B., Butler, D., Ficzere, S., \& Kuperis, S. (1996). Teaching students with learning disabilities and low achievers to plan, write and revise opinion essays. Journal of Learning Disabilities, 29, 197-212.

Wong, B., Butler, D., Ficzere, S., \& Kuperis, S. (1997). Teaching adolescents with learning disabilities and low achievers to plan, write and revise, compare and contrast essays. Learning Disabilities Research and Practice, 12, 2-15.

Received November, 15, 2005 Revision received March, 20, 2007 Accepted April, 25, 2007 